\title{
Farklı İrrigasyon Solusyonlarının Rezin ve Biyoseramik Esaslı Kök Kanal Patlarının Push-out Bağlanma Dayanımları Üzerine Etkisinin İncelenmesi
}

\author{
Investigation of The Effect of Different Chelation Solutions on the Push-out \\ Bond Strengths of Resin and Bioceramic Based Root Canal Sealers
}

\author{
Melike ÖZBEK $^{1}$ (D) \\ ozbekmelike@yahoo.com
}

\author{
Gözde KOTAN $^{1}$ (D) \\ gozdekotann@gmail.com
}

Betül Aycan UYSAL ${ }^{* 1}$ (D)

balim@bezmialem.edu.tr

\section{öz}

Amaç: Borik asit (BA) ve etilendiamintetraasetik asit (EDTA) solusyonlarının rezin ve biyoseramik esaslı kök kanal patlarının bağlanma dayanımına etkisini araştırmaktır.

Gereç ve Yöntemler: Bu çalıșmada tek köklü dișlerden elde edilmiș 36 adet kök kesiti kullanılmıștır. Diș pulpa boșluğuna bitișik kök dentini üzerinde $0.9 \mathrm{~mm}$ çapında standardize delikler olușturulmuștur. Örnekler \%5 sodyum hipoklorit $(\mathrm{NaOCl})$ solusyonuna maruz bırakıldıktan sonra, final irrigasyon solüsyonunun tipine göre rastgele üç gruba ayrılmıştır: Grup 1: \%17 EDTA; Grup 2: \%10 BA; Grup 3: salin. Her irrigasyon solusyonu 5 dakika uygulandıktan sonra gruplar, kullanılan kök kanal patına göre üç alt gruba ayrılmıștır: Grup A: AH Plus, Grup B: EndoSequence BC Sealer, Grup C: MTA Fillapex. Kök kanal patlarının push-out bağlanma dayanım değerleri hesaplanmıștır. İstatistiksel analiz çift yönlü ANOVA, Tukey post-hoc ve Tamhane's T2 testleri ile gerçekleştirilmiştir ( $\mathrm{p}=0.05)$.

Bulgular: EndoSequence BC Sealer'ın bağlanma dayanımı kullanılan irrigasyon solusyonundan etkilenmemiştir $(p=0.785)$. Tüm irrigasyon gruplarında, MTA Fillapex'in bağlanma dayanımı EndoSequence BC Sealer ve AH Plus kanal patlarından anlamlı olarak düşük bulunmuștur $(\mathrm{p}=0.000)$.

Sonuçlar: EDTA ve BA solüsyonları AH Plus ve MTA Fillapex kanal patlarının bağlanma dayanımlarını salin grubuna göre artırmıștır. EndoSequence BC Sealer'ın bağlanma dayanımı ise, kullanılan irrigasyon solüsyonundan etkilenmemiştir.

Anahtar Kelimeler: Biyoseramik esaslı kanal patı, Borik asit, Push-out bağlanma dayanımı, Resin esaslı kanal patı

Geliș: 05.07.2021

Kabul: 09.08.2021

Yayın: 25.08.2021

\begin{abstract}
Aim: To investigate the effect of boric acid (BA) and ethylenediaminetetraacetic acid (EDTA) solutions on the bond strength of resin- and bioceramic-based sealers.

Material and Methods: Thirty-six root sections obtained from single-rooted teeth were used. Standardized holes of 0.9 $\mathrm{mm}$ diameter were created on the root dentin adjacent to the dental pulp cavity. After the samples had been exposed to $5 \%$ sodium hypochlorite $(\mathrm{NaOCl})$, they were randomly divided into three groups according to the type of final irrigation solution: Group 1: 17\% EDTA; Group 2: 10\% BA; Group 3: saline. After applying each irrigation solution for 5 minutes, the groups were divided into three subgroups according to the root canal sealer used: Grup A: AH Plus, Grup B: EndoSequence BC Sealer, Grup C: MTA Fillapex. The bond strength values of root canal sealers were calculated. Statistical analysis was performed with two-ways ANOVA analysis, Tukey post-hoc and Tamhane's T2 tests $(\mathrm{p}<0.05)$.

Results: The bond strength value of EndoSequence BC Sealer was not affected by the irrigation solution used ( $\mathrm{p}=0.785)$. The bond strength of MTA Fillapex was significantly lower than EndoSequence BC Sealer and AH Plus in all irrigation solutions $(\mathrm{p}=0.000)$.

Conclusions: The EDTA and BA increased the bond strengths of the AH Plus and MTA Fillapex to a greater extent than the saline. The bond strength of EndoSequence BC Sealer was not affected by the type of irrigation solution used.
\end{abstract}

Keywords: Bioceramic-based canal sealer, Boric acid, Push-out bond strength, Resin-based canal sealer

$\begin{array}{lll}\text { Received: 05.07.2021 Accepted: 09.08.2021 Published: 25.08.2021 } & \text { Ac21 }\end{array}$

Atıf / Citation: Özbek M, Kotan G, Uysal BA. Farklı irrigasyon solusyonlarının rezin ve biyoseramik esaslı kök kanal patlarının push-out bağlanma dayanımları üzerine etkisinin incelenmesi. NEU Dent J. 2021;2:56-61.

* Sorumlu Yazar / Corresponding Author

1. Bezmialem Vakıf Üniversitesi Diș Hekimliği Fakültesi, Endodonti AD, İstanbul, Türkiye 


\section{Gíriş}

İdeal bir endodontik tedavi için kök kanal sisteminin etkin bir şekilde temizlenmesi, patojenik mikroorganizmaların uzaklaştırılması ve enfeksiyonun yeniden yayılmasının önlenmesi için üç boyutlu kanal dolumu oldukça önemlidir. ${ }^{1}$ İdeal bir kök kanal irrigasyonu, başarılı kök kanal dolumu için de önemli bir basamaktır. ${ }^{2}$ Sodyum hipoklorit $(\mathrm{NaOCl})$, etkili antimikrobiyal özellikleri ve organik doku çözme kapasitesi ile kök kanal irrigasyonu sırasında kullanılan en yaygın kök kanal irrigantıdır., ${ }^{2,3} \mathrm{NaOCl}$, smear tabakasını kaldıramadığından, etilendiamintetraasetik asit (EDTA) gibi şelatlama solusyonlarının kullanılması tavsiye edilmektedir. ${ }^{4}$ İrrigasyon solüsyonlarının kök dentinin mineral içeriğini değiștirdiği ve mekanik özellikler üzerinde çeşitli etkilere neden olduğu gösterilmiştir., ${ }^{5,6}$ Son dönemde kullanılmaya başlanan ve antiseptik, antibakteriyel ve antifungal özelliklere sahip olduğu gösterilen borik asidin (BA) de kök kanal sisteminde endodontik irrigasyon ajanı olarak kullanımı gündemdedir. ${ }^{7}$ Daha önceki çalışmalarda BA'nın smear tabakası, dentin mineral içeriği ve kanal patlarının bağlanma dayanımı üzerine etkileri araștırılmıştır ${ }^{8,9}$ Literatürde çeşitli irrigasyon protokollerinin farklı kanal patlarının push-out bağlanma gücü üzerindeki etkisini değerlendiren çalıșmalar bulunmaktadır. ${ }^{10,11}$

Kök kanal patları, kanal dolum materyali ve dentin duvarları arasında sızıntıya sebep olan alanları ortadan kaldırmak ve restoratif ișlemler sırasında dolgu materyalinin bütünlügünü korumak için kullanılmaktadır. ${ }^{12-14}$ Kök kanal patlarının kök kanal yüzeyine bağlanma gücü arttıkça endodontik tedavinin başarı oranının da arttığı tahmin edilmektedir. ${ }^{15,16}$ Endodontide farklı özellikte kök kanal patları kullanılmaktadır. ${ }^{17}$ AH Plus (Dentsply Sirona, Konstanz, Almanya) mükemmel fiziksel özelliklere sahip rezin esaslı bir dolgu materyalidir ve endodontik çalıșmalarda altın standart olarak kabul edilmektedir. ${ }^{18-20}$ Kalsiyum silikat esaslı materyaller ise, mükemmel sızdırmazlık yetenekleri ve biyouyumlulukları nedeniyle son 20 yılda endodontide birçok klinik uygulamada kullanılmıștır. ${ }^{21}$ MTA Fillapex (Angelus, Londrina, Brezilya) ve EndoSequence BC Sealer (Brasseler ABD, Savannah, GA, ABD) gibi kök kanal patları, biyouyumluluk ve sızdırmazlık konusunda gelişmiş fiziksel ve kimyasal özelliklere sahiptir. ${ }^{22}$

Mevcut literatürde biyoseramik esaslı kök kanal dolgu patlarının push-out bağlanma dayanım özellikleri üzerine BA solüsyonunun etkisi ile ilgili herhangi bir çalışma bulunmamaktadır. Bu nedenle bu çalıșmanın amacl, farklı final irrigasyon solüsyonlarından sonra kullanılan biyoseramik esaslı kanal patlarının push-out bağlanma dayanımını incelemektir. Boș hipotezler aşağıdaki şekilde kurulmuştur:
1. Biyoseramik esaslı kök kanal patları ve rezin esash kök kanal patları arasında push-out bağlanma dayanımı açısından fark yoktur.

2. BA solüsyonu, EDTA ve saline göre kök kanal patlarının push-out bağlanma dayanımını daha fazla artırmaktadır.

\section{GEREÇ VE YÖNTEMLER}

"Bu çalıșmanın prosedürü, Bezmialem Vakıf Üniversitesi Girișimsel Olmayan Araștırmalar Etik Kurulu tarafından onaylanmıștır (25.02.2021-E.6324). Çalışmamızda 36 adet kırık, çatlak ve restorasyon bulunmayan, çekilmiş tek köklü insan diși kullanılmıștır. Dișlerin kuron kısımları su soğutması altında uzaklaștırıldıktan sonra, su altında soğutmalı bir elmas disk (Metkon Instruments Inc., Bursa, Türkiye) ve kesme makinesi (Mecatome T180; Presi, Eybens, Fransa) kullanılarak her dişten 1.00 mm kalınlığında longitudinal kesitler alınmıştır. Kök kanal boşluğunu taklit etmek için kesitlerin koronal, orta ve apikal üçlülerinde radiküler dentin yüzeyinde standartlaştırılmıș sabit genișlikte toplam 6 adet delik açılmıș$\operatorname{tır}^{23}$ Her bir delik, dentin dilimi üzerinde $0.90 \mathrm{~mm}$ çapındaki fissür bir elmas frez ile kök kanal mesafesi sabit tutularak delinmiştir ( $n=216$; Şekil 1). Tüm numuneler \%5 $\mathrm{NaOCl}$ ile doldurulmus plastik bir kapta 5 dakika bekletildikten sonra final irrigasyon solüsyonuna göre rastgele üç gruba ayrılmıştır:

Grup I: \%17 EDTA (ENDO-Solution, Cerkamed, Nisko, Polonya),

Grup II: \%10 BA (Etimaden, Ankara, Türkiye),

Grup III: salin solüsyonu (kontrol).

Şekil 1: Dentin dilimi üzerinde oluşturulan yapay delikler ve deney düzeneği

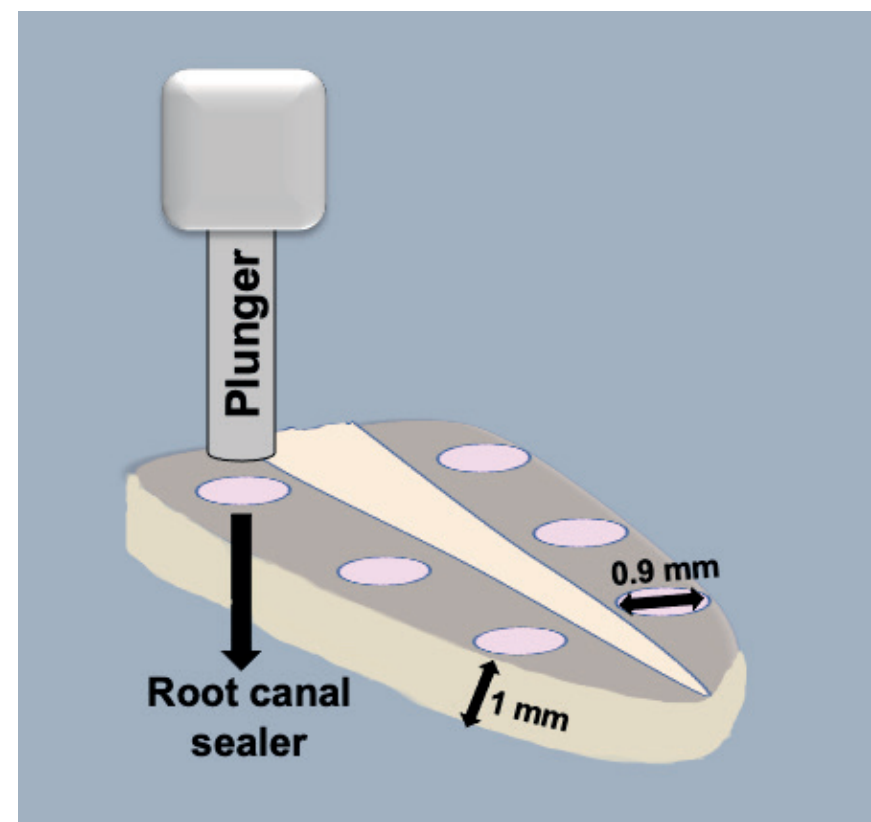


Her dentin dilimi, üç solüsyonundan biri ile doldurulmuş olan kaplara 5 dakika boyunca daldırılmıștır. Numuneler irrigasyon solüsyonunun kalıntılarını gidermek için yumuşak ve emici pamuklarla kurutulmuștur. Daha sonra her grup kullanılan dolguya göre üç eşit alt gruba ayrılmıștır: Grup A: AH Plus (Dentsply Sirona, Konstanz, Almanya), Grup B: EndoSequence BC Sealer (Brasseler USA, Savannah, GA, ABD), Grup C: MTA Fillapex (Angelus, Londrina, PR, Brezilya). Oluşturulan delikler, üreticinin talimatlarına göre hazırlanan kök kanal patları ile doldurulmuş̧tur. Aynı dentin dilimi üzerindeki tüm boşluklar için tek tip kök kanal patı kullanılmıștır. Daha sonra örnekler, patın sertleșmesi için 7 gün boyunca $37^{\circ} \mathrm{C}^{\prime} \mathrm{de}$ ve $\% 100$ nemde bekletilmiştir.

Kök kanal patı ile doldurulan deliklerin ortasına, 0.8 $\mathrm{mm}$ çapında metal bir plunger yerleştirilmiştir. Dolgu materyalleri ile dentin duvarları arasındaki bağlanma gücünü test etmek için gereken kuvvet Universal Test Cihazı (Instron Universal; Elista, İstanbul, Türkiye) kullanılarak ölçülmüștür. Materyallerin üzerine $0.5 \mathrm{~mm} / \mathrm{dk}$ hızda ve $5 \mathrm{kN}$ yük ile kuvvet uygulanmıştır. MPa cinsinden olan push-out bağlanma kuvveti, $\mathrm{F} / 2 \pi \mathrm{r} \cdot \mathrm{h}$ formülü kullanılarak hesaplanmıștır. F kırılma durumundaki yük $(\mathrm{N}), \pi=3.14$, $\mathrm{r}$ dolgu malzemesinin ölçülen yarıçapı $(\mathrm{mm})$ ve $\mathrm{h}$ dolgu malzemesinin yüksekliğini $(\mathrm{mm})$ ifade etmektedir. ${ }^{24}$ Ölçümler tamamlandıktan sonra, stereomikroskop altında (Olympus Corporation, Taichung, Tayvan) 8X büyütmede materyallerin adeziv, kohesiv ya da karışık bağlanma başarısızlıkları incelenmiştir.

\section{İstatistiksel Analiz}

Calıșmada elde edilen bulgular değerlendirilirken, istatistiksel analizler için IBM SPSS Statistics 22 (IBM
SPSS, Türkiye) programı kullanılmıștır. Parametrelerin normal dağılıma uygunluğu Kolmogorov-Smirnov ve Shapiro Wilks testleri ile değerlendirilmiş olup parametrelerin normal dağllım gösterdiği belirlenmiştir. İrrigasyon solüsyonlarının push-out bağlanma gücü üzerindeki etkisi çift yönlü ANOVA testi ile değerlendirilmiş ve post hoc analizlerde grupların varyansları homojen ise Tukey HSD test, homojen değil ise Tamhane's T2 test kullanılmıştır $(p<0.05)$.

\section{BULGULAR}

Çalışmada test edilen materyallerin ortalama push-out bağlanma gücü değerleri Tablo 1'de gösterilmiştir. EndoSequence BC Sealer'in tüm irrigasyon solüsyon gruplarındaki push-out bağlanma gücü değerleri arasında anlamlı bir fark bulunamamıștır $(\mathrm{p}=0.785)$. MTA Fillapex kanal patı, solüsyon tipinden bağımsız olarak en düşük bağlanma dayanım değerlerini göstermiş̦tir ( $p=0.000)$. Salin solüsyonunun, EndoSequence BC Sealer hariç, kök kanal patlarının bağlanma gücünü azalttığı görülmüștür. Şekil 2 'de, çalışmanın sonuçları grafik halinde sunulmuştur.

En yaygın bağlanma başarısızlığı türleri, MTA Fillapex grubunda (\%69) karışık ve AH Plus grubunda (\%90) kohesiv ve EndoSequence BC Sealer grubunda (\%83) kohesiv olarak bulunmuștur. Bunun yanı sira MTA Fillapex grubunda \%31 oranında kohesiv, AH Plus grubunda \%10 oranında karışık, EndoSequence BC Sealer grubunda ise \%17 oranında karıșık bağlantı hatası gözlenmiștir. Numunelerden elde edilen stereomikroskop görüntüleri Şekil 3'te gösterilmiștir.

Tablo 1. Test edilen tüm kök kanal patlarının push-out bağlanma değerleri

\begin{tabular}{|c|c|c|c|c|}
\hline \multirow{3}{*}{$\begin{array}{l}\text { Irrigasyon } \\
\text { solusyonu }\end{array}$} & \multicolumn{3}{|c|}{ Kök kanal patı } & \multirow[b]{3}{*}{$\mathbf{p}$} \\
\hline & $\begin{array}{c}\text { Endosequence BC } \\
\text { Sealer }\end{array}$ & MTA Fillapex & AH Plus & \\
\hline & Ort. \pm SD & Ort. \pm SD & Ort. \pm SD & \\
\hline Salin & $11.2 \pm 6.65^{\mathrm{Aa}}$ & $0.91 \pm 0.35^{\mathrm{Ba}}$ & $6.36 \pm 3.61^{\mathrm{Ca}}$ & $0.000 *$ \\
\hline EDTA & $11.57 \pm 4.7^{\mathrm{Aa}}$ & $1.28 \pm 0.48^{\mathrm{Bb}}$ & $11.47 \pm 4.09^{\mathrm{Ab}}$ & $0.000^{*}$ \\
\hline Borik asit & $12.4 \pm 6.7^{\text {Аа }}$ & $1.03 \pm 0.41^{\mathrm{Bc}}$ & $14.81 \pm 6.26^{\mathrm{Ab}}$ & $0.000^{*}$ \\
\hline $\mathbf{p}$ & 0.785 & $0.011^{*}$ & $0.000 *$ & \\
\hline
\end{tabular}

İki Yönlü ANOVA Testi ${ }^{*} p<0.05$

Satırlardaki büyük harfler, kök kanal patları arasındaki farkı göstermektedir.

Sütunlardaki küçük harfler, irrigasyon solüsyonları arasındaki farkı göstermektedir. 
Şekil 2: Kullanılan irrigasyon solüsyonlarına göre kök kanal patlarının push-out bağlanma dayanım değerlerinin (MPa) grafiği

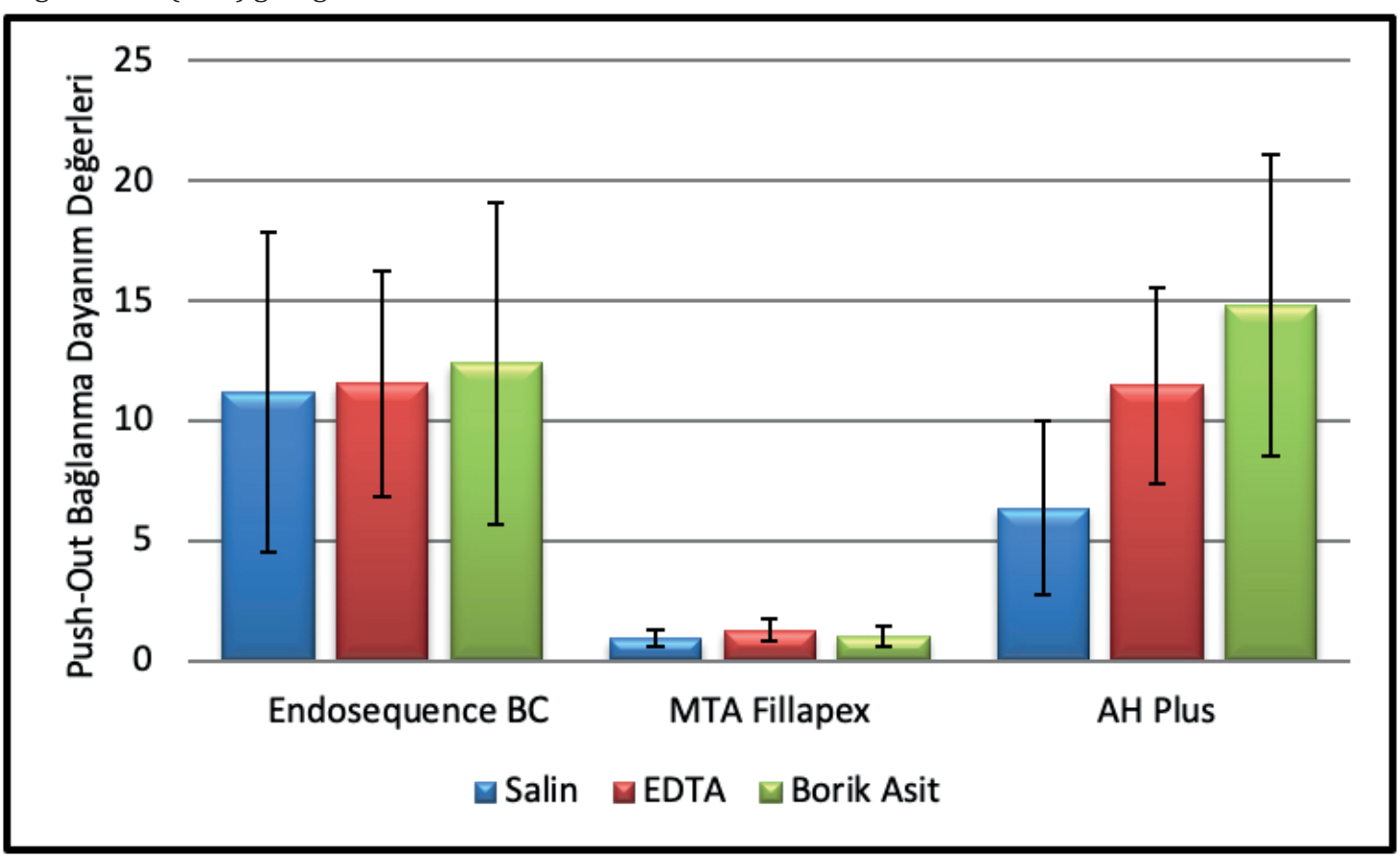

Şekil 3: Farklı kök kanal patlarının stereomikroskop altında 8X büyütmede incelenen bağlanma hataları

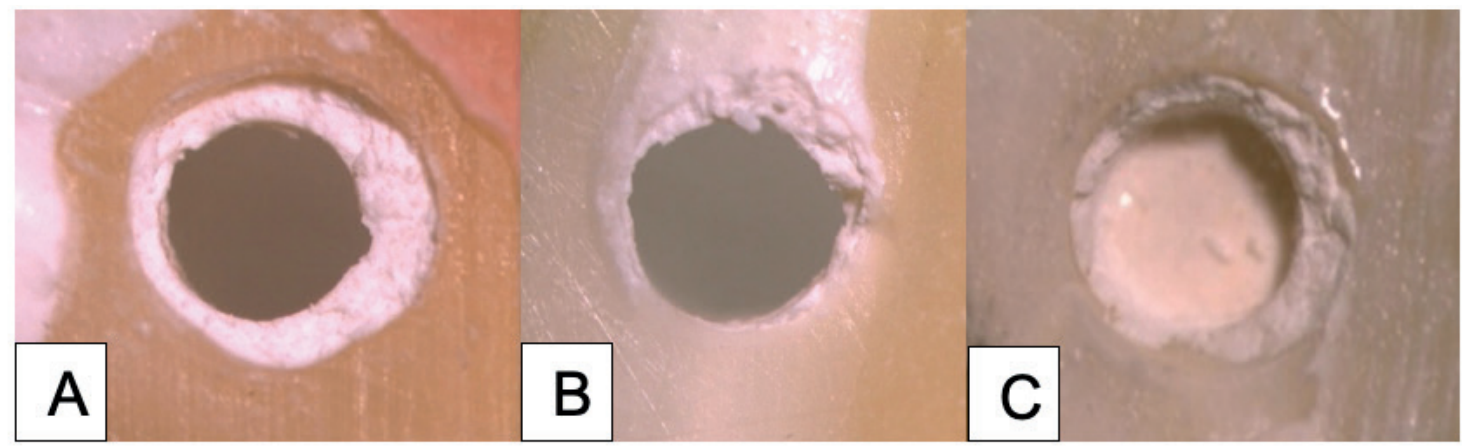

(A) EndoSequence BC Sealer, kohesiv kopma hatası; (B) MTA Fillapex, karıșılk kopma hatası;

(C) AH Plus, kohesiv kopma hatası

\section{TARTIȘMA}

Bu çalışmada, çeşitli şelasyon solüsyonları kullanılarak üç farklı kök kanal patının kök dentini üzerindeki push-out bağlanma dayanımları karşılaştırılmıştır. Bildiğimiz kadarıyla, BA solüsyonunun kök kanal patlarının bağlanma gücü üzerindeki etkisini inceleyen ilk çalışma budur. Push-out bağlanma dayanımları açısından kullanılan kök kanal patları arasında istatistiksel olarak anlamlı bir fark bulunmuştur, bu nedenle birinci boș hipotez reddedilmiștir.

Kök kanal patlarının dentin ve güta-perkaya bağlanma kabiliyeti, kök kanal dolumunun sizdırmazlığına katkıda bulundukları için endodontik tedavide büyük önem tașımaktadır. ${ }^{25,26,27} \mathrm{Bu}$ çalışmada rezin esaslı kanal patı olarak AH Plus, biyoseramik esash pat olarak MTA Fillapex ve EndoSequence BC Sealer tercih edilmiştir. Kök kanal patlarının kanal duvarı- na adezyonunu değerlendirmek için yaygın olarak uygulanan bir yöntem olan push-out bağlanma testi bildirilmiş olsa da, ${ }^{28}$ bu testlerin standardizasyon sağlama ve klinik durumu öngörme açısından eksiklikleri olabileceği vurgulanmıştır. ${ }^{29}$ Geleneksel push-out yönteminde, çekilmiş dişlerin anatomik kök kanalları kullanılmaktadır. Bu nedenle, bu tasarımda karmaşık kök anatomisi nedeniyle standart bir taban çizgisine dayalı güvenilir sonuçlar elde etmek mümkün olmayabilir. ${ }^{30} \mathrm{Bu}$ çalışmada, push-out modelinin geçerliliğini artırmak ve gruplar arası daha objektif karşılaștırmayı sağlamak için yapay standart delikler oluşturulmuştur.

Tedesco ve ark. (2014), AH Plus ve MTA Fillapex dahil olmak üzere dört kök kanal patının bağlanma gücünü değerlendirmiş ve $\mathrm{AH}$ Plus'ın diğer tüm kanal patlarından daha iyi sonuçlar verdiğini kanıtla- 
mıștır. ${ }^{31}$ AH Plus'ın biyoseramik dolgu materyallerine kıyasla daha güçlü bir bağlanma gücü gösterdiği daha önceki bir çalıșmada da kanıtlanmıștır..$^{32}$ Çeșitli endodontik patların dentin duvarına bağlanma dayanımının push-out test yöntemiyle karşılaștıran bașka bir çalışmada, EndoSequence BC Sealer'ın bağlanma dayanımının MTA-Filllapex'ten daha yüksek oldugu bulunmuștur. ${ }^{33}$ Bizim çalıșmamızda EndoSequence BC Sealar ve AH Plus, her solüsyon grubunda MTA-Fillapex'ten daha iyi sonuçlar göstermiştir. Bu sonucun ortaya çıkmasının nedeni, MTA Fillapex'ten kalsiyum ve hidroksil iyonlarının salınmasının apatit oluşumuna neden olması ve bu yapının düşük adezyon kapasitesine sahip olması gösterilebilir. ${ }^{33} \mathrm{Ay}-$ rıca bağlanma başarısızlıkları incelendiğinde, MTA Fillapex'in karışık bağlanma hatasına uygun şekilde dentinden kopmaya meyilli olduğu tespit edilmiștir. Diğer kök kanal patları dentin duvarından tamamen ayrılmadan kendi içinde kohesiv bağlantı hataları gösterirken, MTA Fillapex'in daha çok karıșık bağlantı hatası göstermesinin nedeninin zayıf adezyon özelliği ile ilgili olduğu düşünülebilir.

BA'nın diş hekimliğinde kullanımı ile ilgili literatürdeki sınırlı çalışmalardan biri Culhaoğlu ve arkadaşları tarafından 2017 'de yapılmıştır. ${ }^{34}$ Çalışma, fiber post ve dentin arasındaki çeșitli simanların bağlanma dayanımları üzerinde BA solusyonunun etkisini değerlendirilmiș ve \%10 BA ve EDTA solüsyonlarının simanların bağlanma gücünü arttırdığını göstermiştir. ${ }^{34}$ Bizim çalışmamızda da bu çalışmaya benzer şekilde, EDTA ve BA ile irrigasyonun MTA-Fillapex ve AH Plus kök kanal patlarının bağlanma gücünü arttırdığı gözlenmiştir. Bu durum, irrigasyon solüsyonunun smear tabakasını ortadan kaldırarak dolgu materyalinin dentin tübüllerine nüfuz etmesine izin vermesi ile kök kanal patlarının bağlanma dayanımını artırmasına bağlanabilir. ${ }^{35}$ Ancak EndoSequence BC Sealer grubunun bağlanma dayanım değerlerinin kullanılan irrigasyon solüsyonundan etkilenmediği gözlenmiştir ( $\mathrm{p}=0.785)$. Bu nedenle ikinci sıfır hipotezi de reddedilmiştir.

İrrigasyon solüsyonun diş yapısı üzerindeki etkisi öncelikle temas süresine ve konsantrasyona bağlldir. De-Deus ve ark. (2006) ve Ulusoy ve ark. (2013) dentinin fiziksel özelliklerini değerlendirdikleri çalışmalarında irrigasyon solusyonlarını kök kanalına 5 dakika boyunca uygulamışlardır. ${ }^{36,37}$ Bu çalışmalara benzer şekilde, bizim çalışmamızda da EDTA ve BA irrigasyon solüsyonları, oluşturulan yapay deliklere 5 dakika süreyle uygulanmıştır. Tüm solüsyonların eşit sürede uygulanması çalışmanın standardizasyonunu sağlamak için tercih edilmiştir.

Bu deneysel çalışmamızın bazı sınırlamaları mevcuttur. İlk olarak, frezle standart şekilde açılmış delikler, doğal kök kanal anatomisinin değişkenlerini taklit edememiş olabilir, bu nedenle sonuçlar klinik koşul- ları öngörmeyebilir. İkinci olarak, bağlanma gücünü test etmek için yapay kanallar sadece kök kanal patı ile doldurulmuştur. Bu yöntemin, kök kanal patları üzerindeki tüm stresi doğrudan dentin duvarlarına ilettiği için uygun bağlanma gücünü göstermede daha etkili olduğu düşünülse de, ${ }^{30,32}$ klinik durumu tam anlamıyla yansıtamamış olabilir. Son olarak, mevcut çalıșmada kısa vadede bağlanma gücü başarısızlığı ölçülmüştür. Daha uzun süreler boyunca bağlanma gücü değişikliklerini gözlemlemek için daha fazla çalışmaya ihtiyaç vardır.

\section{SONUÇ}

Mevcut araştırmanın sinırlamaları dahilinde, MTA-Fillapex' in final irigasyon solüsyonundan bağımsız olarak diğer kök kanal patlarından daha düşük push-out bağlanma gücü değerlerine sahip olduğu görülmüștür. Final irrigasyon solüsyonu olarak kullanılan \%10 BA ve \%17 EDTA, test edilen kök kanal patlarından AH Plus ve MTA Fillapex'in bağlanma gücünü artırırken, EndoSequence BC Sealer herhangi bir irrigasyon solüsyonundan etkilenmemiștir.

\section{KAYNAKLAR}

1. Verma D, Taneja S, Kumari M. Efficacy of different irrigation regimes on the push-out bond strength of various resin-based sealers at different root levels: An in vitro study. J Conserv Dent. 2018;21,125-129.

2. Siqueira JF Jr. Rôças IN Favieri A, Lima KC. Chemomechanical reduction of the bacterial population in the root canal after instrumentation and irrigation with $1 \%, 2.5 \%$, and $5.25 \%$ sodium hypochlorite. J Endod. 2000;26,331-334.

3. Beltz RE, Torabinejad M, Pouresmail M. Quantitative analysis of the solubilizing action of MTAD, sodium hypochlorite, and EDTA on bovine pulp and dentin. $J$ Endod. 2003;29,334-337.

4. Zehnder M. Root canal irrigants. J Endod. 2006;32,389398.

5. Ari H, Erdemir A. Effects of endodontic irrigation solutions on mineral content of root canal dentin using ICP-AES technique. J Endod. 2005;31,187-189.

6. Saha S, Sharma V, Bhardwaj A, Shrivastava P, Saha M, Dubey S, et al. Effectiveness of Various Endodontic Irrigants on the Micro-Hardness of the Root Canal Dentin: An in vitro Study. J Clin Diagn Res. 2017;11,ZC01ZC04.

7. Meers PD, Chow CK. Bacteriostatic and bactericidal actions of boric acid against bacteria and fungi commonly found in urine. J Clin Pathol. 1990;43,484-487.

8. Turk T, Kaval ME, Şen BH. Evaluation of the smear layer removal and erosive capacity of EDTA, boric acid, citric acid and desy clean solutions: an in vitro study. BMC Oral Health. 2015;15,104.

9. Akman M, BellI S, Olcay K. ve Özçopur B. The Effect of Boric Acid on Root Dentin Mineral Content and Bond Strength of AH-Plus: A SEM-EDX Study. Turkiye Klinikleri J Dental Sci. 2016;22,14-20 
10. Leal F, Simão RA, Fidel SR, Fidel RA, do Prado M. Effect of final irrigation protocols on push-out bond strength of an epoxy resin root canal sealer to dentin. Aust Endod J. 2015; 41,135-139.

11. Antunes PVS, Flamini LES, Chaves JFM, Silva RG, Cruz Filho AMD. Comparative effects of final canal irrigation with chitosan and EDTA. J Appl Oral Sci. 2020;28, e20190005.

12. Orstavik D, Eriksen HM, Beyer-Olsen EM. Adhesive properties and leakage of root canal sealers in vitro. Int Endod J. 1983;16,59-63.

13. Lee KW, Williams MC, Camps JJ, Pashley DH. Adhesion of endodontic sealers to dentin and gutta-percha. $J$ Endod. 2002;28,684-688.

14. DeCleen MJ. The relationship between the root canal filling and post space preparation. Int Endod J. 1993;26,53-58.

15. Saleh IM, Ruyter IE, Haapasalo MP, Orstavik D. Adhesion of endodontic sealers: scanning electron microscopy and energy dispersive spectroscopy. J Endod. 2003; 29,595-601.

16. Sly MM, Moore BK, Platt JA, Brown CE. Push-out bond strength of a new endodontic obturation system (Resilon/Epiphany). J Endod. 2007;33,160-162.

17. Shokouhinejad N, Gorjestani H, Nasseh AA, Hoseini A, Mohammadi M, Shamshiri A. R. Push-out bond strength of gutta-percha with a new bioceramic sealer in the presence or absence of smear layer. Aust Endod J. $2013 ; 39,102-106$.

18. Duarte MAH, Ordinola-Zapata R, Bernardes RA, Bramante CM, Bernardineli N, Garcia RB, et al. Influence of calcium hydroxide association on the physical properties of AH Plus. J Endod. 2010; 36,1048-1051.

19. Marin-Bauza GA, Abi Rached-Junior FJ, Souza-Gabriel AE, Sousa-Neto MD, Miranda CES, Silva-Sousa YTC. Physicochemical properties of methacrylate resin-based root canal sealers. J Endod. 2010; 36,15311536.

20. Brackett MG, Martin R, Sword J, Oxford C, Rueggeberg FA, Tay FR, et al. Comparison of seal after obturation techniques using a polydimethylsiloxane-based root canal sealer. J Endod. 2006;32,1188-1190.

21. Parirokh M, Torabinejad M ve Dummer PMH. Mineral trioxide aggregate and other bioactive endodontic cements: an updated overview - part I: vital pulp therapy. Int Endod J. 2018; 51,177-205.

22. Al-Haddad A, Che Ab Aziz ZA. Bioceramic-Based Root Canal Sealers: A Review. Int J Biomaterials. 2016; 9753210.

23. Huffman B, Mai S, Pinna L, Weller R, Primus C, Gutmann J, et al. Dislocation resistance of ProRoot Endo Sealer, a calcium silicate-based root canal sealer, from radicular dentine. Int Endod J. 2009; 42,34-46.

24. Skidmore LJ, Berzins DW, Bahcall JK. An in vitro comparison of the intraradicular dentin bond strength of Resilon and gutta-percha. J Endod. 2006;32,963-966.

25. Saleh IM, Ruyter IE, Haapasalo M, Ørstavik D. The effects of dentine pretreatment on the adhesion of root-canal sealers. Int Endod J. 2002; 35,859-866.

26. Rajput JS, Jain RL, Pathak A. An evaluation of sealing ability of endodontic materials as root canal sealers. J Indian Soc Pedod Prev Dent. 2004;22,1-7.

27. Saunders EM, Saunders WP, Rashid MY. The effect of post space preparation on the apical seal of root fillings using chemically adhesive materials. Int Endod J. $1991 ; 24,51-57$.

28. Pane ES, Palamara JEA, Messer HH. Critical Evaluation of the Push-out Test for Root Canal Filling Materials. J Endod. 2013; 39, 669-673.

29. Chen WP, Chen YY, Huang SH ve Lin CP. Limitations of Push-out Test in Bond Strength Measurement. J Endod. 2013; 39, 283-287.

30. Scelza MZ, da Silva D, Scelza P, de Noronha F, Barbosa IB, Souza E, et al. Influence of a new push-out test method on the bond strength of three resin-based sealers. Int Endod J. 2015; 48, 801-806.

31. Tedesco M, Felippe M, Felippe W, Alves AMH, Bortoluzzi E ve Teixeira C. Adhesive Interface and Bond Strength of Endodontic Sealers to Root Canal Dentine After Immersion in Phosphate-Buffered Saline. Mic Res Tech. 2014;77, 1015-22.

32. Prado MC, Carvalho NK, Vitti RP, Ogliari FA, Sassone LM ve Silva E. Bond Strength of Experimental Root Canal Sealers Based on MTA and Butyl Ethylene Glycol Disalicylate. Braz Dent J. 2018; 29, 195-201.

33. Madhuri GV, Varri S, Bolla N, Mandava P, Akkala LS ve Shaik J. Comparison of bond strength of different endodontic sealers to root dentin: An in vitro push-out test. J Conserv Dent. 2016; 19, 461-464.

34. Culhaoglu AK, Özcan E, Kilicarslan MA ve Seker E. Effect of Boric Acid Versus Conventional Irrigation Solutions on the Bond Strength Between Fiber Post and Root Dentin. J Adhes Dent. 2017;19, 137-146.

35. Zmener O, Spielberg C, Lamberghini F ve Rucci M. Sealing properties of a new epoxy resin-based root-canal sealer. Int Endod J. 1997;30, 332-334.

36. De-Deus G, Paciornik S, Mauricio MH. Evaluation of the effect of EDTA, EDTAC and citric acid on the microhardness of root dentine. Int Endod J. 2006;39,401407.

37. Ulusoy OI, Gorgul G. Effects of different irrigation solutions on root dentine microhardness, smear layer removal and erosion. Aust Endod J. 2013;39, 66-72. 